\title{
DIVERSITY AND ANTIBIOTIC SUSCEPTIBILITY OF BACTERIA IN WATER OF HOTEL RESTAURANTS IN DHAKA CITY
}

\author{
MD. ABDUL KARIM ${ }^{1}$ AND NASRIN SULTANA* \\ Laboratory of Microbiology, Department of Botany, \\ University of Dhaka, Dhaka 1000, Bangladesh
}

\begin{abstract}
Present study was conducted to determine the microbiological status of water from dispensers in different roadside hotel and restaurants of Dhaka city. Samples were collected from seven hotel and restaurants. Aerobic heterotrophic bacterial count ranged between $1.5 \times 10$ and $8.8 \times 10^{3} \mathrm{cfu} / \mathrm{ml}$. Enteric and related bacterial abundance in MacConkey, SS and Cetrimide agar media ranged from 0 to $4.9 \times 10^{6}, 0$ to $2.1 \times 10^{5}$ and 0 to $1.2 \times 10^{6} \mathrm{cfu} / \mathrm{ml}$, respectively. In total, 28 bacterial isolates were obtained during the study period. Among them, 15 were heterotrophic isolates and 13 were enteric and related bacteria. Among 15 aerobic heterotrophic isolates, 11 were gram positive and five were gram negative. Out of 11 gram positive isolates, 7 belonged to the genus Bacillus viz. B. circulans, B. subtilis, B. stearothermophilus, B. brevis and B. cereus and one to coccus viz. Micrococcus roseus. The other gram positive species were Kurtia gibsonii, Auriobacterium liguefaciens and Curtobacterium luteum. Four gram negative isolates were Neisseria elongate sub. spp. glycolytica, Plesiomonas shigelloides, Pseudomonas fluorescens biovar 1, Pseudomonas aeruginosa. All 13 enteric and related isolates were gram negative, short rod; and non-spore formers and belonged to the genera Escherichia, Klebsiella, Shigella and Pseudomonas. Among all isolates, two were resistant and six were susceptible to all five antibiotics.
\end{abstract}

Key words: Bacteria, Drinking water, Hotels, Restaurant, Dhaka city, Antibiotic resistant

\section{Introduction}

Transmission of pathogens through contaminated water is a significant cause of illness worldwide. It has been estimated that one-third of gastrointestinal illnesses are caused by contaminated drinking water (Hunter 1997), and $4 \%$ of all deaths worldwide are due to polluted drinking water and poor sanitation (Prüss et al. 2002). In developed nations water quality assessments and treatment facilities have been introduced to reduce microbial contamination, resulting in a significant reduction in drinking water-related illnesses and deaths. Water treatment commonly involves the reduction of organic matters and other contaminants via coagulation and sedimentation, separation of any remaining solids via filtration and finally disinfection using chemical oxidants or ultraviolet (UV) radiation. The addition of chemical oxidants such as chlorine and monochloramine is the most common method of drinking water disinfection (USEPA 1999).

\footnotetext{
* Corresponding author
} 
The level of treatment required varies from system to system, with some drinking water distribution systems receiving only one or two levels of treatment, while others require multiple treatments to create water suitable for end use.

Some members of the total coliform group are considerably more resistant to disinfection than E. coli and are better indicators of poor disinfection (WHO 2004 and Fricker and Eldred 2009). The presence of total coliforms in a water distribution system can also indicate a lack of system integrity (Besner et al. 2002). Thus, total coliform bacteria are commonly used to evaluate the general sanitary quality of water (WHO 2004 and Fricker and Eldred 2009).

Outbreaks of water borne diseases continue to occur throughout the world but especially serious in developing countries (WHO 1993 and Reynolds et al. 2007). Diarrheal diseases are endemic in Bangladesh. In 2008, an estimated 20,000 children less than 5 years old died of diarrheal diseases in Bangladesh (Huda et al. 2012). E. coli is commonly isolated from water sources, including the municipal water supply of Dhaka city (Islam et al. 2010). One study from India and another from Canada also reported the presence of antibiotic resistant E. coli in drinking water (Coleman et al. 2012 and Pathak and Gopal 2008). Armstrong et al. (1981) found that multiply antibiotic resistant (MAR), Gram positive cocci, e.g. Staphylococcus and MAR gram negative, non-fermentative rods Pseudomonas, Alcaligenes, Moraxella-like group $\mathrm{M}$ and Acinetobacter were more common in drinking waters than in untreated source waters.

According to the WHO guideline values for bacteriological quality, all water intended for drinking and treated water in the distribution system should not have detectable levels of E. coli or thermo-tolerant coliform bacteria in any $100 \mathrm{ml}$ of the water sample (Sobsey and Bartram 2003). Unlike cholera, humans infected with salmonellae can carry the bacteria in the gut without signs of disease. Infected humans can harbor the bacteria for considerable periods of time. About $5 \%$ of patients clinically cured from typhoid fever remain carriers for months or even years. These people can be chronic holders of the bacterium in the gut, and constitute the main reservoir of the bacteria in the environment (Popoff and Le Minor 2005). Shigellosis or Bacillary dysentery is also an important waterborne disease which is an infectious disease caused by a group of bacteria called Shigella.

Dhaka is the $9^{\text {th }}$ largest city and also $28^{\text {th }}$ among the most densely populated cities in the world. Everyday lots of people take their meals from roadside hotel and restaurants. Besides high cost bottle water, low cost dispenser water is now very popular. The present study was undertaken for enumeration of both heterotrophic and enteric bacteriological abundance and comparison microbial abundances among those hotels and restaurants situated in Dhaka city. 


\section{Materials and Methods}

Study site and sampling: In the present study water samples were collected from seven hotel restaurants in Dhaka city during the period from April 2013 to March 2014. Sterile plastic bottles were used for sample collection. Industrially prepared drinking water supplied to these restaurants were collected during sampling period.

Isolation of bacteria: Nutrient agar (NA) medium was used for the enumeration and isolation of aerobic heterotrophic bacteria, while MacConkey agar (Difco), SS agar (Diagnostic Pasteur), Cetrimide agar (Difco) media were used for the determination and isolation of enteric bacteria present in water samples. The $\mathrm{pH}$ of the medium was adjusted to 7 , since $\mathrm{pH}$ of most of the samples were within the range of 6.58-6.95. Three different techniques viz. Pour plate technique (Greenberg et al. 1998), Spread plate technique (Sharp and Lyles 1969), Membrane filtration technique (Atlas et al. 1995) were used for the enumeration and isolation of bacteria. All the culture plates were marked with sample name and incubated at $37{ }^{\circ} \mathrm{C}$ in the dark for 48 hours. Bacterial colony counting was made with the help of a digital colony counter (DC-8 OSK 100086, Kayagaki, Japan). Discrete bacterial colonies were isolated immediately after counting. In case of MacConkey agar medium, pink or brick red colonies were considered as coliform bacteria while white colonies were considered as non-lactose fermenter, whereas in SS agar medium, black colonies were considered as highly pathogenic. In cetrimide agar medium, green colonies were considered Pseudomonas and pathogenic. During this investigation, of the total 40 isolates from nutrient agar medium, finally 28 isolates were randomly selected and purified for detailed study required for identification.

Physico-chemical properties of water: Temperature of Water samples was measured by a mercury centigrade thermometer.

(After collection of samples) $\mathrm{pH}$ was measured in the laboratory by an electric $\mathrm{pH}$ meter (Jenway 3310 pH meter, U.K).

Antibiotic sensitivity test: Five common antibiotics viz. Doxycycline. Penicillin G, Erythromycin, Gentamycin and Streptomycin were used to carry out the antibiotic sensitivity test.

Identification of bacteria: Important physiological and biochemical characteristics were studied for the identification of the selected isolates. Bergey's Manual of Systematic Bacteriology (Sneath et al. 1986) was followed for the identification of aerobic heterotrophic bacteria while, Manual for laboratory investigations of acute enteric infections (WHO 1987) and Bergey's manual of systematic bacteriology (Krieg and Holt 1984) were consulted for gram negative, enteric and related bacteria. 


\section{Results and Discussion}

The physico-chemical properties of the samples are presented in Table 1. The water temperature ranged between $19^{\circ} \mathrm{C}$ and $28^{\circ} \mathrm{C}$.Minimum water temperature was $19^{\circ} \mathrm{C}$ recorded in sample No. 5. Maximum was $28^{\circ} \mathrm{C}$ recorded in the sample No. 2 and sample No. 7. The $\mathrm{pH}$ of the sample water ranged between 6.58 and 6.95. Sample No. 7 showed the highest $\mathrm{pH}$ value (6.95) while the lowest $\mathrm{pH}$ value (6.58) was recorded in sample No. 6 .

Table 1. Water temperature and $\mathrm{pH}$ of different samples.

\begin{tabular}{clcc}
\hline Sample No. & \multicolumn{1}{c}{ Sampling sites } & Water temperature $\left({ }^{\circ} \mathrm{C}\right)$ & $\mathrm{pH}$ \\
\hline 1 & Star hotel and kabab & 23 & 6.68 \\
2 & Rajdhani hotel and restaurant & 28 & 6.60 \\
3 & Pita ghor hotel and restaurant & 20 & 6.68 \\
4 & Al-Arju hotel and restaurant & 25 & 6.90 \\
5 & Sayedabad hotel and restaurant & 19 & 6.66 \\
6 & Hotel Kisukkhon & 25 & 6.58 \\
7 & Allah'r dan hotel and restaurant & 28 & 6.95 \\
\hline
\end{tabular}

Table 2. Bacterial count ( $\mathrm{cfu} / \mathrm{ml})$ of the water samples of different hotel restaurants.

\begin{tabular}{|c|c|c|c|c|c|}
\hline \multirow[b]{2}{*}{$\begin{array}{l}\text { Sample } \\
\text { No. }\end{array}$} & \multirow[b]{2}{*}{ Sampling sites } & \multirow[b]{2}{*}{$\begin{array}{c}\text { Aerobic } \\
\text { heterotrophic } \\
\text { bacteria }\end{array}$} & \multicolumn{3}{|c|}{ Enteric and related bacteria } \\
\hline & & & $\begin{array}{l}\text { MacConkey } \\
\text { agar }\end{array}$ & SS agar & $\begin{array}{c}\text { Cetrimide } \\
\text { agar }\end{array}$ \\
\hline 1 & Star hotel and Kabab & $7.9 \times 10^{2}$ & NG & NG & NG \\
\hline 2 & $\begin{array}{l}\text { Rajdhani hotel and } \\
\text { restaurant }\end{array}$ & $1.1 \times 10^{3}$ & $3.2 \times 10^{2}$ & NG & NG \\
\hline 3 & $\begin{array}{l}\text { Pita ghor hotel and } \\
\text { restaurant }\end{array}$ & $8.8 \times 10^{3}$ & $1.8 \times 10^{2}$ & $2.0 \times 10^{1}$ & NG \\
\hline 4 & $\begin{array}{l}\text { Al-Arju hotel and } \\
\text { restaurant }\end{array}$ & $1.3 \times 10^{3}$ & $3.0 \times 10^{1}$ & $1.8 \times 10^{5}$ & $1.2 \times 10^{6}$ \\
\hline 5 & $\begin{array}{l}\text { Sayedabad hotel and } \\
\text { restaurant }\end{array}$ & $1.0 \times 10^{3}$ & $8.0 \times 10^{1}$ & $2.0 \times 10^{1}$ & NG \\
\hline 6 & Hotel Kisukkhon & $1.5 \times 10^{1}$ & $2.4 \times 10^{1}$ & $1.7 \times 10^{1}$ & $4.1 \times 10^{1}$ \\
\hline 7 & $\begin{array}{l}\text { Allah'r dan hotel and } \\
\text { restaurant }\end{array}$ & $1.1 \times 10^{3}$ & $4.9 \times 10^{6}$ & $2.1 \times 10^{5}$ & NG \\
\hline
\end{tabular}

$\mathrm{NG}=$ No growth

Aerobic heterotrophic bacterial count was higher than the count of enteric and related bacteria (Table 2). Aerobic heterotrophic bacterial count ranged between $1.5 \times 10$ and 8.8 $\times 10^{3} \mathrm{cfu} / \mathrm{ml}$. In SS agar average bacterial count varied from 0 to $2.1 \times 10^{5} \mathrm{cfu} / \mathrm{ml}$. Bacterial count on MacConkey agar ranged between 0 and $4.9 \times 10^{6} \mathrm{cfu} / \mathrm{ml}$. In cetrimide agar medium bacterial count was within the range of 0 to $1.2 \times 10^{6} \mathrm{cfu} / \mathrm{ml}$ and among the seven samples, 5 samples showed no bacterial growth (Table 2). Out of 15 selected 
isolates, PG 11 and PG 23 were resistant, while RH 11, AD 11, SK 41, PG 21, RH 13 and HK 11 were susceptible to all five selected antibiotics (Table 3).

Table 3. Antibiotic sensitivity of the selected isolates.

\begin{tabular}{|c|c|c|c|c|c|}
\hline \multirow{3}{*}{$\begin{array}{l}\text { Isolate } \\
\text { No. }\end{array}$} & \multicolumn{5}{|c|}{ Inhibition zone measured in diameter $(\mathrm{mm})$} \\
\hline & \multicolumn{5}{|c|}{ Name of the Antibiotics } \\
\hline & E-15 & P-10 & GEN-10 & S-10 & DO-30 \\
\hline AD-10 & $\mathrm{R}$ & $\mathrm{R}$ & S (18) & $\mathrm{R}$ & S (14) \\
\hline PG-11 & $\mathrm{R}$ & $\mathrm{R}$ & $\mathrm{R}$ & $\mathrm{R}$ & $\mathrm{R}$ \\
\hline PG-22 & S (20) & $S(15)$ & S (29) & S (14) & S (20) \\
\hline PG-23 & $\mathrm{R}$ & $\mathrm{R}$ & $\mathrm{R}$ & $\mathrm{R}$ & $\mathrm{R}$ \\
\hline RH-11 & $S(25)$ & $S(12)$ & $S(16)$ & $S(12)$ & $S(21)$ \\
\hline AA-11 & S (08) & $\mathrm{R}$ & $\mathrm{S}(22)$ & $S(14)$ & $\mathrm{S}(10.5)$ \\
\hline AA-13 & $\mathrm{R}$ & $\mathrm{R}$ & $S(22)$ & $S(19)$ & S (11) \\
\hline AD-11 & S (24) & S (02) & S (19) & $S(21)$ & S (15) \\
\hline SK-41 & S (13) & S (18) & S (13) & $S(17)$ & S (17) \\
\hline PG-21 & S (21) & S (09) & S (17) & S (12) & S (19) \\
\hline RH-13 & S (12) & S (08) & S (14) & S (16) & S (14) \\
\hline AA-12 & S (03) & $\mathrm{R}$ & $S(21)$ & $S(21)$ & S (14) \\
\hline SH-11 & $\mathrm{R}$ & $\mathrm{R}$ & $S(21)$ & S (14) & $S(02)$ \\
\hline SK-11 & $\mathrm{R}$ & $\mathrm{R}$ & $S(14)$ & $\mathrm{R}$ & S (18) \\
\hline HK-11 & S (14) & $\mathrm{S}(01)$ & S (14) & S (11) & S (15) \\
\hline
\end{tabular}

$\mathrm{S}=$ Sensitive, $\mathrm{R}=$ Resistant, E-15 = Erythromycin, $\mathrm{P} 10=$ Penicillin $\mathrm{G}$,

$\mathrm{S}-10=$ Streptomycin, GEN-10 = Gentamycin, N30 = Doxycycline.

Consulting all observed and tested characters of the bacterial isolates, identification was done. Ninety eight bacterial isolates were obtained during the study period. Among them 15 were heterotrophic isolates and 13 were enteric and related bacteria (Table 4). From the 15 aerobic heterotrophic bacteria 11 were gram positive bacterial isolates of which 7 belong to the genus Bacillus and one gram positive bacterial isolate to Micrococcus. Under the genus Bacillus the provisionally identified species were Bacillus circulans (two isolates), Bacillus subtilis, Bacillus stearothermophilus, Bacillus brevis and Bacillus cereus (two isolates). The four heterotrophic gram negative bacterial isolates were Neisseria elongate sub. spp. glycolytica, Plesiomonas shigelloides, Pseudomonas fluorescens biovar 1 and Pseudomonas aeruginosa. All 13 enteric and related isolates were gram negative, short rod and non-spore former and belonged to the genera Escherichia coli, Klebsiella, Shigella and Pseudomonas. 
Table 4. Provisional identification of the selected bacterial isolates.

\begin{tabular}{|c|c|c|c|}
\hline \multirow[b]{2}{*}{ Isolate No. } & \multirow[b]{2}{*}{$\begin{array}{c}\text { Source (sample } \\
\text { no.) }\end{array}$} & \multicolumn{2}{|c|}{ Species identified } \\
\hline & & Gram positive & Gram Negative \\
\hline $\mathrm{AD}-10$ & 7 & Aureobacterium liquefaciens & - \\
\hline PG-11 & 3 & Kurtia gibsonii & - \\
\hline PG-22 & 3 & Bacillus stearothermophilus & - \\
\hline PG-23 & 3 & Bacillus brevis & - \\
\hline RH-11 & 2 & Bacillus subtilis & Escherichia coli \\
\hline RH-17 & 2 & - & Klebsiella sp. \\
\hline AA-11 & 4 & Bacillus cereus & - \\
\hline AA-13 & 4 & Curtobacterium luteum & - \\
\hline AA-02 & 4 & - & Escherichia coli \\
\hline AA-18 & 4 & - & Shigella sp. \\
\hline AD-11 & 7 & Bacillus cereus & - \\
\hline AD-06 & 7 & - & Escherichia coli \\
\hline $\mathrm{AD}-14$ & 7 & - & Shigella sp. \\
\hline SK-41 & 1 & Bacillus circulans & - \\
\hline PG-21 & 3 & Bacillus circulans & - \\
\hline PG-06 & 3 & - & Escherichia coli \\
\hline PG-02 & 3 & - & Shigella sp. \\
\hline RH-13 & 2 & - & $\begin{array}{l}\text { Neisseria elongate subspp } \\
\text { glycolytica. }\end{array}$ \\
\hline AA-12 & 4 & - & Plesiomonas shigelloides \\
\hline AA-03 & 4 & - & Pseudomonas aeruginosa \\
\hline SH-11 & 5 & - & $\begin{array}{l}\text { Pseudomonas fluorescens } \\
\text { biovar } 1\end{array}$ \\
\hline SH-21 & 5 & - & Escherichia coli \\
\hline SH-25 & 5 & - & Shigella sp. \\
\hline SK-15 & 1 & - & Pseudomonas aeruginosa \\
\hline HK-11 & 6 & Micrococcus roseus & - \\
\hline HK-05 & 6 & - & Pseudomonas aeruginosa \\
\hline HK-19 & 6 & - & Escherichia coli \\
\hline HK-22 & 6 & - & Shigella sp. \\
\hline AD-18 & 7 & - & Klebsiella sp. \\
\hline
\end{tabular}

According to "WHO guidelines for drinking water quality", Escherichia coli (fecal coliform bacilli) must not be present in any $100 \mathrm{ml}$ sample of (1) all water directly intended for drinking, (2) treated water entering the distribution system and (3) treated water in the distribution system. For effective disinfection, there should be a residual concentration of free chlorine of $\geq 0.5 \mathrm{mg} /$ litre after at least 30 min contact time at $\mathrm{pH}$ $<0.8$. Chlorine residual should be maintained throughout the distribution system. At the point of delivery, the minimum residual concentration of free chlorine should be 0.2 $\mathrm{mg} / \mathrm{litre}$. The guideline value for chlorine used in water treatment that is of health significance in drinking-water is $5.0 \mathrm{mg} /$ litre (WHO 2008). The results clearly showed that all the samples except sample no. 1 contaminated with $E$ coli, Shigella sp., Pseudomonas and Klebsiella sp., which are pathogenic for human health. All the samples 
showed presence of high number of bacteria as revealed by heterotrophic plate count, which is far beyond the limit set by WHO and USEPA for drinking water considered to be safe to public health.

\section{References}

Armstrong, J.L., D.S. Shigeno, J.J. Calomiris and R.J. Seidler. 1981. Antibiotic-resistant bacteria in drinking water.Appl. Environ. Microbiol. 42(2): 277-283.

Atlas, R.M., A.E. Brown and L.C. Parks. 1995. Laboratory Manual of ExperimentalMicrobiology. Mosby-Year Book, Inc., St. Louis. pp. 1-565.

Besner, M-C., V. Gauthier, P. Servais and A. Camper. 2002. Explaining theoccurrence of coliforms in distribution systems. J. AWWA 94:95-109.

Coleman, B.L., M.I. Salvadori, A.J. McGeer, K.A. Sibley and N.F. Neumann. 2012. The role of drinking water in the transmission of antimicrobial resistant E. coli.Epidemiology and Infection 140: 633-642.

Fricker, C.R. and B.J. Eldred. 2009. Identification of coliform genera recoveredfrom water using different technologies. Lett. Appl. Microbiol. 49: 685-688.

Greenberg, A.E., J.J. Connors, D.G.J. Jenkins and M.A.H. Franson. 1998. Standard methods for examination of water and wastewater $\left(20^{\text {th }}\right.$ Ed.). APHA. Washington DC. p. 265.

Huda, T.M., L. Unicomb, R.B. Johnston, A.K. Halder, M.A.Y. Sharker. 2012. Interim evaluation of a large scale sanitation, hygiene and water improvement programme on childhood diarrhea and respiratory disease in rural Bangladesh. Social Science \& Medicine 75: 604611.

Hunter, P.R. 1997. Waterborne disease: epidemiology and ecology. John Wiley and Sons, Chichester, United Kingdom.

Islam, S., H.A. Begum and N.Y. Mili. 2010. Bacteriological Safety Assessment of Municipal Tap Water and Quality of Bottle Water in Dhaka City: Health Hazard Analysis. Bangladesh.J. Med. Microbiol. 4(1): 9-13.

Krieg, N.R. and J.G. Holt (Eds.). 1984.Bergey's Manual of Systematic Bacteriology. The Williams and Wilkins Company, Baltimore, USA. Vol.1: pp. 140-575.

Pathak, S.P., K. Gopal. 2008. Prevalence of bacterial contamination with antibiotic resistant and enterotoxigenic fecal coliform treated drinking water. J. Toxicol. Environ. Health 71: 427-433.

Popoff, M.Y. and L.E. Le Minor. 2005. Genus Salmonella. In: Bergey's Manual of Systematic Bacteriology ( $2^{\text {nd }}$ Ed), Vol. 2, Part B. Brenner, D.J., N.R. Krieg, J.T. Staley, G.M. Garrity, D.R. Boone, P.D. Vos, M. Goodfellow, F.A. Rainey and K.H. Schleifer (Eds). Springer.NY. pp. 764-799.

Prüss, A., D. Kay, L. Fewtrell and J.Bartram. 2002. Estimating the burden ofdisease due to water, sanitation and hygiene at a global level. Environ Health Perspect. 110: 537-542.

Reynolds, K.A., K.D. Mena and C.P. Gerba. 2007.Risk of water-borne illness via drinking water in the United States.Rev. Environ.Contam.Toxicol. 192: 117-158.

Sharp, M.S. and S.T. Lyles. 1969.Laboratory Instruction in Biology of Microorganisms.Saint Louis the CV Mosley Company. pp. 23-25.

Sneath, P.H.A., N.S. Mair, M.E. Sharpe and J.G. Holt (Eds.). 1986. Bergey's manual of systematic bacteriology $\left(9^{\text {th }} \mathrm{Ed}\right.$.). The Williams and Wilkins Co., Baltimore, USA. Vol. 2, p. 1599.

Sobsey, M.D. and S. Bartram. 2003. Water quality and health in the new millennium: the role of the World Health Organization Guidelines for Drinking-Water Quality. Forum Nutr. 56: 396-440. 
USEPA. 1999. EPA guidance manual: alternative disinfectants and oxidants, EPA 815-R-99-014. US Environmental Protection Agency, Washington, DC.

WHO. 1987. Manual for laboratory investigations of acute enteric infections. World Health Organization p. 1-109.

WHO. 1993. Guidelines for drinking water quality (Vol. 1). World Health Organization, Geneva pp 1-29.

WHO. 2004. Guidelines for drinking-water quality, (3rd ed.), Vol 1. Recommendations. World Health Organization, Geneva, Switzerland.

WHO. 2008. Guidelines for drinking-water quality, ( ${ }^{\text {rd }}$ Ed.). (Incorporating first \& second addenda), Vol. 1 - Recommendations, Geneva.

(Revised copy received on 4-11-2017) 